\title{
SOCIAL DISADVANTAGE: CHALLENGE FOR EDUCATIONAL SCIENCES AND EDUCATORS
}

\author{
Martin Stanoev, Dušan Janák, Kateřina Tvrdá
}

\begin{abstract}
The aim of the theoretical/empirical study is the conceptual development of the concept of social disadvantage. Social disadvantage is a technical term as enshrined in the Act no. 561/2004 of legal code, on preschool, primary, secondary, tertiary technical and other training. According to the study authors, the importance of understanding this issue is currently growing. In practice, however, this term is associated with ambiguous interpretations. The study seeks to further develop and expand the findings of a case study of educational schemes of the towns of Krnov and Sokolov, which was focused just on the issue of education of socially disadvantaged pupils. The study describes the legislative basis of social disadvantage and understanding of this concept by pedagogicalpsychological advisory centres and ordinary educators, as was captured by two case studies. In conclusion, based on analytical findings, the authors suggest a division of the concept of social disadvantage in three dimensions and formulate recommendations for practice.
\end{abstract}

\section{Keywords}

social disadvantage, social education, social risk, social exclusion

\section{Introduction}

Keller (2011, pp. 37-42) identifies current new social risks as the failure of three traditional pillars protecting the modern society against risk: the family, the labour market and the social state. The problem of new social risks came to the foreground more noticeably at the time when the economic crisis broke out in 2008, as well as in connection with so called austerity measures of the government presided by Petr Nečas. At present, the current Czech society is facing increasing homelessness (MPSV 
(Ministry of Labour and Social Affairs), 2013), socially excluded localities (GAC, 2015), overindebtedness ${ }^{1}$ and increasing number of beneficiaries of poverty benefits (MPSV, 2015).

But the above stated phenomena rather constitute the "most visible iceberg top". A larger segment of the society is affected by many other social risks consisting in high divorce rate ${ }^{2}$, uncertainty of job stability or of sufficient security to be provided by social state systems in old age or in adverse social situation. As Keller (2011, pp. 155-157) mentions, the responsibility for the risks is asymmetrical: some people "undertake the risk" in order to increase their profit, while other people "bear the risk" in form of threat of poverty and adverse social situation. While the old risks depended, as Keller says, to a considerable degree on personal indispositions and were handled by the system, the new risks are produced by the system and are supposed to be handled individually (Keller, 2011, p. 44).

Although we may not accept Keller's analysis of new social risks responding to the economic crisis and to the neo-liberal discourse as a whole and in all aspects, it is indisputable that the educational sciences and practice in the Czech Republic are facing the problem of social disadvantage in a different form than in late 1990s. And it is also indisputable that the educational scheme of elementary and secondary schools can constitute an important tool to mitigate social risks and social disadvantage.

The goal of this empirical-theoretical study consists in analyzing the term of social disadvantage and the relation to its use in practice; as it is shown below, it is a quite multivocal term for many actors; its legislative stipulation is obsolete from the amendment of the School Act in 2016 (for the main changes see Zezulková, Kaleja 2016), but it will still constitute an important concept in the practice of inclusive education, and it is therefore relevant to know the interpretation of educators working in the elementary schools and pedagogical-psychological advisory centres. The statements of educators on social disadvantage were analyzed by qualitative and quantitative research methods. The methodology and the context of the research, the case studies of the educational schemes of the two towns stated above, will be specified in more detail below. The analysis of the perspectives of the educators on the issue of social disadvantage constitutes the base of further conceptual elaboration of the concept and of the formulation of suggestions for practice.

Although this study takes account also of the education of the Roma ethnic group, intensively focused by expert literature on social disadvantage in the context of

\footnotetext{
1 The media recently informed about the statistical data of the Executor Chamber about the number of multiple executions. According to the information from the media from October 2015, the number of people under four or more seizures amounted to 377,000 . And the number of people under ten and more seizures amounted to 120,000 (Švejdová, 2015).

2 According to a summarizing information of the Czech Statistical Office (ČSÚ) (2015), the divorce rate from 2001 to 2013 has been at a level of $45-50 \%$ marriages ending by divorce.
} 
education in the Czech Republic (e.g. Němec et al., 2010a, Kaleja et al., 2011), the above stated Keller's theses suggest that the problem of social disadvantage exceeds this issue by far ${ }^{3}$.

In conclusion of the introductory part, the relation of social disadvantage and social exclusion as theoretical concepts used by the study authors in their research should be determined, although this study deals primarily with the issue of how the concept is handled by people from pedagogical practice who acted as respondents of the study. We consider social disadvantage a specific disposition for social exclusion. Not every person who is socially disadvantaged must be socially excluded. On the other hand, being socially excluded is an obvious disadvantage. Therefore everybody who is socially excluded is socially disadvantaged by definition. Social disadvantage is thus a broader category than social exclusion. The following part deals with the concept of social disadvantage, whose priority resulted from the legislative framework applicable at the time of writing the study. The legal regulations concerning social disadvantage in relation to education have changed. Social disadvantage as a legal term is not so important any more, but it keeps existing as a social phenomenon. It can even turn out to be a more burning social problem when the adequate denomination disappears from official reflection. At such point, it may start putting on its usual disguises of inborn dispositions and biologizing social stereotypes.

\section{Interpretation of social disadvantage: views of experts and elementary school teachers in case study of two educational schemes}

\section{Methodological procedure and research context}

The empirical study constituting the base for this analysis examined the transformation of educational schemes of the towns of Krnov and Sokolov. Both case studies were at the same time a part of a statewide project with other publication outputs related to the issue of social disadvantage and social exclusion (Kaleja, 2015; Kaleja et al, 2015; Kolaříková, 2015; Zezulková, 2015). Several years ago, both towns closed down the elementary schools attended primarily by Roma children. Both educational schemes in both towns had to cope with specific problems related to the above stated step. The transformation of the elementary school scheme in Krnov (implemented in school year 2008/2009) and in Sokolov (implemented in school year 2011/2012) was linked to two

\footnotetext{
${ }^{3}$ For example Vítková et al. (2007) focus not only on the Roma but also on pupils-foreigners and on pupils with behaviour disorders in the framework of social disadvantage problems. But we consider this a too narrow focus as well.
} 
problems. On one hand, there was the demand to reduce the school network because of decreasing number of pupils; on the other hand, there was the demand to reduce social selectivity of the educational scheme, i.e. to eliminate the existence of a school attended almost exclusively by socially disadvantaged pupils coming mainly from the Roma ethnic group. This study (Janák, Stanoev et al., 2015) showed that some problems transgressed the borders of the two above stated towns. One of the motives to write this study consisted in contributing to a more general discussion exceeding the borders of the two towns. One of the topics deserving wider attention and discussion concerns the perception of social disadvantage by educators and the issue of approach to this problem by educational sciences and practice.

The study was divided into four stages:

- Stage 1: At the beginning, a pilot study was carried out in form of non-structured interviews with relevant communication partners (school headmasters, heads of education departments) and secondary data and information sources were prepared to form the base for description of educational schemes of both towns and their transformations.

- Stage 2: That basic descriptive picture was followed by the first stage of qualitative research aimed at ascertaining the perception of the educational scheme in relation to social selectivity by different types of respondents (primarily educators, representatives of the towns, representatives of the non-profit sector, pedagogical-psychological advisory centres), as well as their evaluation of the recent changes.

- Stage 3: The findings of the qualitative research were complemented by the quantitative questionnaire research focused primarily on elementary school educators, with research questions operationalized and created on the basis of preceding qualitative research. A comprehensive research was carried out among elementary school educators of both towns, with a return rate of $84 \%$ and the 317 analyzed questionnaires.

- Stage 4: The last stage included focus groups with educators and parents as the last base for interpretation of the research findings. The scenario of the focus groups was created on the basis of the findings from the preceding research stages. Furthermore, additional interviewing was carried out in some kindergartens and secondary schools.

Although the study makes use of both qualitative and quantitative research techniques, the general logic of the given study relied upon the qualitative paradigm: it was aimed at a thorough description and interpretation of the phenomenon in question. The study also used the photographs made by Jindřich Štreit, a professor of the Silesian University in Opava (a set of almost 1,500 photographs), during the implementation of the study in Krnov. Furthemore, the study tries to elaborate and extend the findings concerning the issue of socially disadvantaged pupils. And its goals are not limited only to analyze the situation in the educational schemes of Krnov and Sokolov. 


\section{Social disadvantage in the context of activities of pedagogical-psychological advisory centres}

Based on a phone inquiry, the Pedagogical-psychological advisory centre of Karlovy Vary - branch of Sokolov assesses the social disadvantage of pupils according to the following indicators:

- bilingualism in the family

- the child's not attending any preschool facilities

- the child's growing up in a "handicapped" - incomplete, numerous - family

- illiteracy of the parents or of the legal representative

- the child's insufficient stimulation in his/her natural environment

- the child's skills and knowledge depending on age (retardation)

The pedagogical-psychological advisory centre of Bruntál (where the pupils from Krnov belong) often verifies the information acquired from the parents in cooperation with the headmasters of the elementary schools and with the educators' assistants. The assessed criteria include the following facts:

- the pupil lives in a socially excluded locality

- the family receives poverty benefits

- one of the parents is serving imprisonment sentence

- based on expert experience with the pupil

The practice of the pedagogical-social advisory centres of Sokolov and Bruntál shows that children with social disadvantage caused by "family environment with low socialcultural status or endangerment by socially pathological phenomena" are officially diagnosed at a minimal degree (as compared to children-foreigners and children with ordered upbringing in a custody centre or imposed protective upbringing). But that does not mean that a number of other pupils do not have any educational needs, as the interviews with elementary school teachers of both towns showed.

On one hand, the identification of special educational means should help the pupils to overcome educational barriers; on the other hand, the need to have the social disadvantage "certified" by a psychological-pedagogical advisory centre constitutes other barriers. First, the parents had to overcome the barriers connected with submitting the application, arranging a meeting in the advisory centre, filling out a questionnaire and visiting the advisory centre with the child. Second, the diagnosis of social disadvantage as the cause of the pupil's school failure is very stigmatizing. It is particularly negatively approached in case of the majority part of the poverty-endangered families.

\section{Social disadvantage as seen by the questionnaire inquiry among educators}

When researching the transformation of the educational systems of Krnov and Sokolov, we wanted to know how the concept was approached by the educators who are in daily contact with the pupils. In order to reduce the potential halo effect (i.e. the influence 
of the answer to the preceding questions of the questionnaire), we included the openended question "How would you define social disadvantage in relation to education with your own words?" at the very beginning of the questionnaire. The respondents did not get any variants to choose from; their own answers had to be subject to open coding. In spite of some variedness of the answers, the respondents' reactions showed two most important dimensions: poverty and lowly stimulating family environment, although other variants could be found to a lesser extent too. We choose some typical examples from the respondents' answers, both from Krnov and from Sokolov, as no essential difference was identified between the two towns ${ }^{4}$ :

"Social disadvantage is not always related to the approach to education, but only with the fact that poor parents cannot provide their children with extra things, other teaching aids, paid trips, excursions, workshops. The problem rather consists in disrespect for education, easy and simple life, lowly stimulating environment."

In the educators' eyes, social disadvantage in the approach to education is most frequently related to low motivation to education in the families, quite often linked with poverty. The answers show that the concept of social disadvantage in relation to education provokes negative association. The answers repeatedly feature negative prefixes and words: they cannot, don't have, don't want, unsuitable, lack of cooperation, disadvantageous, lack of interest, etc.

It may be primarily caused by an association characteristic of the language concept of "disadvantage" that leads to other negatively structured expressions. On the other hand, the analytical philosophy shows that to mean something is to actually do it and that language expressions are related to actions or activities, respectively. Understanding a language expression is related to understanding a specific activity. Negative connotations of the language expressions may support the social distance that is evident in some respondents' definitions.

We can even find a refusal of the usefulness of the concept of social disadvantage as an artificial problem, as motivation is considered something much more individual and not socially determined, which is aptly illustrated by the following quotations:

"If the child wants to educate himself/herself and is supported by the family, social disadvantage does not play any role."

\footnotetext{
4 The pre-printed answers are not extracts; they always constitute the complete answers to the question "How would you define, in your own words, the social disadvantage in relation to education?" In view of the fact that it is a question of a large questionnaire, the respondents most frequently gave short answers instead of long treatises, to save time. From the perspective of analysis of the answers, it is rather an advantage, as the answers could reflect the most essential primary associations.
} 
"If both the pupil and the family are interested in education, there are no differences."

"They don't have money for interest groups and aids, but there are few of them; the most do have money, but they don't give it!"

"Motivation to achieve results by their own work and diligence is lacking. The parents are indifferent to the children's results and to the teachers' advice."

The above stated answers to the question requiring an own definition of social disadvantage can be interpreted as follows: Social disadvantage is something that, in the respondents' opinion, really exists but does not have substantial influence on the area of education. The child's (individual) motivation and the motivation of the child's family is the key. But the subjective motivation does not depend on objective social position; it does not have the character of an objectively socially determined dis/advantage; it is a subjective drawback with rather indirect link to an objectively disadvantageous situation. In other words, a considerable part of the respondents would probably support the following attitude: They are poor, but if they wanted, they would have good results. But this statement could be unambiguously confirmed only by a replicated questionnaire investigation.

A special chapter with respect to the Czech Republic as a whole and to the towns under research consists in the issue of social chances of the Roma. Statistically expressed, the Roma do not have equal social chances as the rest of the Czech society. They are disadvantaged both in the educational system and in the labour market. On average, the Roma achieve lower education than the Czech population in general and show higher unemployment values as a group. The basic mechanism of their social integration and thus of the comparison of their social chances with the remaining population consists in the area of education. For the above stated reasons, special attention was paid to the issue of ethnic selection, or to the issues related to the educational chances of the Roma in both towns under research, respectively, as well as to the degree of overlap of social disadvantage with ethnicity, as seen by the educators. Some answers to the question requiring the own definition of social disadvantage suggest a very close connection of the concept of social disadvantage with the ethnically based marginalization, as well as the refusal of such concept by pointing out its wrongness. The above stated answers indicate that a part of the educators perceive the question of social disadvantage as automatically connected with ethnicity, or Roma ethnicity, respectively, so that when asked to offer their own definition of social disadvantage in relation to education, they answer by refusing the implicitly supposed ethnic stereotype.

"I don't perceive the Roma ethnicity as a disadvantage."

"The fact of somebody having another nationality does not imply disadvantage in education."

"Based on the thirty years of my practice, I dare to state that nobody is socially disadvantaged with respect to elementary education. Provided the social 
benefits are used for the intended purpose. I don't perceive the Roma ethnicity as a disadvantage but as an excuse."

It seems that three interconnected stereotypes of the relationship between Roma ethnicity and social disadvantage exist in the Czech society, or in its part, respectively: The first stereotype connects social disadvantage in access to education with the Roma ethnicity. The second stereotype expresses the assumption that there is a widespread stereotype connecting social disadvantage with the Roma ethnicity. In other words, the assumption that others think that the Roma are socially disadvantaged. The third stereotype refuses to recognize the Roma ethnicity as a legitimate social disadvantage, extending defensively the second stereotype.

In the Czech society, social disadvantage overlaps with ethnicity at the level of theory, practice and in the educators' mind. The forms of interconnection are quite varied and often ambivalent, including nuances from simple stating of objective connections in own definition of social disadvantage (In some cases, the children's families speak Roma at home, and the children have then problems at school in Czech lessons and in communication in general) to explicit refusal (I don't perceive the Roma ethnicity as a disadvantage), in case of one respondent.

Therefore we tried to specify more precisely, with the help of quantifiable indicators, how the educators perceive the specific link between social disadvantage and the Roma ethnicity, not only at a general level but also in the context of the school at which they work. The set of indicators included in the questionnaire was aimed at different aspects of overlapping of social disadvantage (whose essential features are consensually accepted to some degree by the respondents) with the Roma ethnicity, as seen by the respondents in the context of their specific workplaces.

In spite of some degree of consensus found in the answers of the educators from both towns, there are slight differences, confirmed also by statistic correlations around the value of 0.2 . The analysis shows that in Sokolov, the educators perceive a closer link between social disadvantage in access to education and the Roma ethnicity. The statement "Social disadvantage in access to education overlaps almost completely with Roma ethnicity at our school" was supported by $19 \%$ educators from Krnov as against $28 \%$ educators from Sokolov, while the contrary statement "The number of Roma pupils with social disadvantage in the educational process is lower than the number of other disadvantaged pupils at our school" was supported by $40 \%$ educators from Krnov and by $22 \%$ educators from Sokolov.

In the context of other findings, we consider it adequate to conclude from the respondents' reactions that a higher level of social disadvantage in relation to education linked to the Roma ethnicity could be perceived in Sokolov than in Krnov, which is accompanied by an ambivalent attitude to the Roma, implying both acknowledgement and refusal of social disadvantage. At the same time, it must be highlighted that the above stated differences are significant, but not dramatic. The educators' estimate of the number of Roma pupils also confirms the assumption of a higher number of Roma pupils in Sokolov as against 
Krnov (resulting from the analyses of socially excluded localities in the towns in question: Hůle et al., 2011, Szczepaniková et al., 2013).

From the perspective of the description of social disadvantage in relation to pupils from non-Roma environment, the respondents most frequently deny differences between Roma and non-Roma cases. The most frequently stated difference related to a non-Roma situation of socially complicated access to education consists in having a single parent who is too busy (which prevents the parent from helping the child with the homework), as well as having unemployed parents, which results in poverty. The educators of both towns also do not perceive the place of residence as a too important factor, although the concept of socially excluded localities situated in both towns could suggest it. Only about one fourth of the respondents attaches importance to the place of residence.

\section{Social disadvantage as seen in qualitative research}

\section{Krnov}

The educators in a focus group at one of the elementary school in Krnov agreed that it did not matter whether the socially disadvantaged pupil was or was not a Roma. They rather highlighted the fact that the problem of social disadvantage has been increasing in the non-Roma population. In their opinion, social disadvantage was linked to long lasting unemployment, intergenerational passing of patterns of passivity and dependence on social benefits, poorly stimulating social environment and lacking motivation of the child for work at school, as well as lacking motivation of the parents to search a job. It may be linked to lower intellect, but it can be primarily understood rather as lack of the necessary moral-volitional characteristics in the family, which has impact on the child:

"I don't speak about the Roma here, I speak about the socially weaker persons; there is either lower intellect, or there is no motivation, or there is no functional parent who sits down and gives remedial classes and prepares the child."

"I perceive that at present, it does not concern only the Roma; there is higher and higher percentage of members of the majority society who are twenty or thirty years old and don't go to work."

"If they see that the parent has not been working all life long, then the model is clear to them. If the child sees that I go to work, I leave at a specific time, I return at a specific time, I bring my work home, then the child is quite likely to take it over and to do the same. I will ask him to do it, and I am asking him to do it today already, but if such model doesn't work there any more, or in other words, if they rely that the state or somebody else will sustain them and they don't need to care, so the children take over such models, all the more so as they are their parents' models. Psychologists have known it for centuries, so I am not surprised that the problems are as they are. We are only facing the results." 
The focus group also mentioned the poverty of some families from the majority society as a problem, suggesting that such families may be insufficiently supported by the governmental welfare system. Which is linked to the assumption that poverty need not always imply "social disadvantage" that is related also to other characteristics of the individual or of the family.

"... this teacher has a girl in her class who lives only with the mother; her mother is ill, so she has only limited income. She paid the skiing course and then she did not have money for other school events like cinemas or theatres. She doesn't even have the seventy or eighty CZK because she spent it for that single thing. So it would be good that the town council finds some money for these children to enable them to go somewhere. That girl cannot attend interest groups, because if you want to develop your talent somewhere, it costs money today. It is not an issue of some crowns but of some thousands of crowns. When you see that the child is interested and diligent, it should be helped..."

The statements of some educators showed attempts to perceive the failure of the educational process as a fault of the family: not only a poorly stimulating family environment but poor motivation and generally bad attitude to school. The educator's potential to influence such process is perceived as limited.

"But it cannot be only up to us to push them; the problem is that there is lacking cooperation or that their home environment isn't working well; if you want to live better than we do, you must do something for it - such pressure is missing there. Nothing will come to you by itself. If the children don't hear that at home, we cannot force them here to do something; and particularly if the parent-teacher communication is missing, then the children will keep having the attitude they have."

"They may get motivation at school, but the main motivation should result from the ideas of the pupil, of the pupil's legal representative, about what the pupil will do in life, and that is where our effort runs out. We don't live at home with them. We are responsible for them at school; we even achieve a miracle at school; but the pupil returns home from school, and if he doesn't have the right environment to make himself useful for the society, than the school really cannot help..."

The governmental pressure, i.e. external pressure from the state, exerted through the social department seems to be a corrective tool. The above stated attitude may reflect some helplessness of the teachers with respect to the education of some pupils where the available tools fail:

"A lot of money they get in form of social benefits is not used in favour of the children but in favour of the parents; that should be supervised. I know it is difficult but it should be supervised; if you don't meet your obligations toward 
your children, the benefits will be reduced. I think it wouldn't help immediately, because when we started working a little with the social department and they became aware that the social department knew about it, so it helped in some cases and it didn't help in other cases; but it slowly starts helping, because money is important to them; so I think that it will be the greatest punishment to them: if you don't fulfil your obligations, you will get lower benefits; I think then they would care more about the children."

On the other hand, the teachers in the focus group emphasized that the assessment of the experience with children from socially disadvantaged environment was individual; they definitely didn't state that there were no positive cases at all. Additionally to the above quoted statements, the focus discussion also included opinions that no generalization should be made; children from socially disadvantaged environment differ from each other. The preceding statements can be also interpreted as a frustration and helplessness in relation to the education of some children. On the contrary, the teacher's individual approach combined with empathy can bring results in the teachers' eyes.

When further focusing on the education of Roma children, we can mention the opinion of an elementary school teacher with respect to the approach to Roma children under use of emotions:

\footnotetext{
"Yes, yes, they seem more emotive to me; when I want them to remember something, I must act upon their hearts. And then it works better; when I say: Beware when crossing the street, it may not respect it, but when I say: Beware when crossing the street, or you could get injured, an ambulance would come to pick you up and your mother would cry, then it helps; it is a sort of blackmail from my side, but it works. It must touch the child and then the child takes a lesson from it."
}

It can be assumed that the teacher-child relation can be worked at and that it can constitute the base of educational influence and of motivation of pupils from Roma environment. But the educators mention a specific turn in the education of Roma pupils. They are divided over when it takes place, but they agree that it exists. They either speak of the passage to the higher elementary school or of the onset of puberty. According to the educators, the children become much less influenceable by the teacher at that time. Although it was not named so explicitly, we could seek the differences in social disadvantage by ethnicity here, because the turn was not so emphasized with respect to socially disadvantaged children from the majority population. The turn is related to the influence of peers and of the adolescence:

"It is rather related with the onset of puberty; if the child has one or two C's in the sixth class and then, in the eighth class, it fails in five subjects, then it is unambiguous..."

"The critical years, they constitute an unambiguous fact, it is a completely credible observation, we can't do anything about it..." 
Additionally to the above stated fact, there is another interesting fact: the Roma families are not perceived as a homogeneous group by the educators with respect to the relation to school. The families were frequently divided into two groups: families that cooperate with the school somehow and support their children's education (minority) and families that do not cooperate with the school at all or only under pressure. A remedial class teacher describes the families interested in their children's education with the following words:

"There are two types. There are parents, a minority, who really wish that their children get education, as they perceive it as a value. But that is a non-Roma perspective in principle. It is similar to a situation that if we make value systems, so the Roma, if they don't know that you want to have it there, they won't write it. There are such families, they usually don't live in this locality, but perhaps have their family here, so they naturally come here with their children and they say that they don't want the children to end like all the other people here; they perhaps live somewhere else and attended a special school when they were young, they have problems to find a job, they work in the municipal services or so, but at least they work, and they want their children to have a better life. They are in a minority, but there are some of them. Then the family is motivated, and in such case, when the time of the turn comes, the child may tend to experience the turn, but the family doesn't allow it, watches the child, and the child keeps going to school or learns at home..."

The interviews in Krnov also repeatedly presented information on successful Roma people who have passed the secondary-school leaving examination or have outstanding school results. The focus group held with Roma parents shows that they accept the school somehow in their life, which suggests the conclusion that school has some potential as an inclusive tool. We probably can distinguish Roma families by the importance they attach to school, and for some families, school can constitute one of the key tools to break out of their marginal social position. Yet the inclusion of the Roma minority through school often seems to fail. In our opinion, the approach of some actors in the educational area of Krnov ("the Krnov approach") is beneficial by asking the question: what is going wrong? An important actor of Krnov is the headmaster of an elementary school who, based on his own experience, has developed the theory of failure of the Roma in the educational process and of the cause of their disturbed education consisting primarily in their lacking knowledge, as compared to the majority population.

"It was particularly due to the fact that we found out that the indiscipline and the disorder and the impossibility to teach in those classes was caused primarily by the fact that the children showed a huge difference in knowledge as compared to the other children. Yes, that means that when they were in the sixth class, their learning knowledge was at the level of the third class, and so they didn't 
understand the schoolwork, it was a foreign language, foreign examples to them; so we tried to prepare them and to remove the handicaps from the beginning of the first class."

Based on his analysis of the problem, he created a club for remedial teaching in the excluded locality in cooperation with a non-profit organization. The club is interconnected with the school through Internet applications, allowing communication of the remedial teachers and the school. Furthermore, the school makes use of the work of a field worker who visits the families for example when a child is absent from school. The headmaster actually tries to create system (inclusive) tools in order to avoid a dependence of the educational success only on the teacher-child (family) relation, and he tries to work with social and cultural influences involved in education. In this respect, the problem is not seen in the individual (family) but in the social conditions that must be acted upon. The focus group held at the school in question (another focus group than the above stated one) shows that the teachers at that school did not challenge the given approach to the Roma. In their opinion, the given model works, but not for all pupils from the socially excluded locality, as some families are very difficult to cooperate with. At present, the actors are trying to extend the given model of cooperation to other elementary schools too. The questionnaire research and the qualitative interviews show that the inclusive efforts in Krnov are accompanies by consensus (although restrained in some cases).

\section{Sokolov}

As for education at the elementary school, the government (including the regional and municipal government) was referred to as a considerably important actor, providing the funds to support inclusive education. As one respondent stated, without creating adequate conditions, comparable to those of foreign countries, the results of educational activities will always remain limited:

"I will take it from the teacher's position; it is terrible to have thirty children in a class today. You know that you have a sum of money from which you must pay the teacher and the assistant. You know that it isn't much, but you want them to do a work of some quality. I visited some European schools and I saw it, they have twenty children in a class, the teacher and two assistants. It is a great work, then they can teach across classes, why not. But if you have thirty children, including several handicapped ones, then the teacher would have to be a Komenský raised to the tenth power. He may wish it desperately, he may be educated, he may be interested, but he cannot manage it physically."

The relation between the Roma ethnicity and social disadvantage is complicated, particularly due to the fact that there is no consensus with respect to the meaning of the latter concept. The different understanding of the meanings of the individual words and phrases results from the nature of the actual language. It is therefore not surprising 
that also the focus groups held among educators experienced conflicts of different perspectives of the key concepts used by the actors to try to understand the reality of the educational failures of socially disadvantaged pupils.

The conflict formulated probably most openly was related to the concept of social disadvantage. While a part of the discussants understood it exclusively socio-economically, in the sense of financial or material shortage, others saw also socio-cultural aspects in it, for example the relatively insufficient vocabulary of the Roma children and their specific use of the language. The first quote expresses the disadvantage understood from exclusively economic perspective and opposed to ethnicity by the author. The second quote contains an example of socio-cultural disadvantage linked to the membership of the Roma group. In other words, in the first case, ethnicity is not identified as a distinctive source of social disadvantage, while in the second case it is:

"I strongly disliked the word 'social disadvantage' used in the questionnaire. In my opinion, a single mother with three children is socially disadvantaged, regardless of her origin. She is socially disadvantaged, but that does not mean that her children will attend a special school. Her children may be able to study at the university, but she doesn't have money for it, and that is the social impact. Then we have rich Roma families, and they feature problems too, as their children will not learn and they will not work. And I think that this is not too closely related. It was too prompting from the ethnic perspective, and I think that it is not true. Many socially disadvantaged people just don't admit the disadvantage to us, the parents have different temporary jobs... and try to provide for the child in many ways. Such parents are ashamed of their social disadvantage. But on the other hand, we have a family that have cars, gold, silver, precious stones, and their boy just won't work."

"The children don't speak Czech well, they don't understand a lot of words. They don't understand what you tell them. They learn the words when they use them. Then they seem to be stupid. The teachers in the first class think: 'Well, she doesn't understand me. She isn't able to solve the verbally formulated example.' She reads the example and doesn't understand the word 'flasket'. She doesn't know what it is and then she doesn't know that it contains apples. She doesn't ask. So she would need a translation. They use the Czech language for a purpose: 'Mum, do, give,' and other purpose-built words, but they don't comprehend the colourful character of the Czech language."

If the teacher is not able to identify the language handicap, the socio-cultural incompetence will be mistaken for mental insufficiency. The fragment from the discussion quoted below illustrates the situation; however, it is not evident whether the group of children referred to in the text equals to all children passed from the Sokolovská elementary school that was closed down or whether it represents a subgroup of children with a "mental disorder", as classified by one informant. 
"I can understand that they didn't want the children to do miracles, (but) I never saw such children in the forty years (of my teaching practice), this group of children was extremely difficult to educate. I feel that when we speak Czech to them, they don't understand us at all, as they don't know a lot of words. Such children have no business here. In my opinion, they should go to the special school where they would be fine; a special teacher would work with them and would teach them some basics like reading and calculating. I am not a specialized special teacher, therefore we are catching up on something with them all the time and solving a million of problems."

Nevertheless, it is essential to identify the problem that was highlighted also by an assistant from a practical class. She spoke about a specific group of children who would manage common lessons if they had favourable conditions for it:

"There are children who could be successful if somebody attended to them, but there is no time for it now. Now in this situation, with thirty pupils in class, it is really impossible, you don't have any chance to attend to such children. They sometimes come and sometimes don't come. Such children are well with less pupils in class, and they are well in the special school. I see it myself that some children should go there and some not. I sometimes feel that we have children there that should be returned to the elementary school. But it worked well just at the school where there were few pupils in the classes and there was better chance to attend to them."

In the context of this statement, the problem does not consist in mere transfer of the children to schools outside the main education stream but in the actual unwillingness to deal with the proportion of the socio-cultural particularities of ethnic groups, or to legitimize them as one of the causes of failure of some Roma pupils at elementary schools. The measures aimed at pupils with special educational needs may provoke the impression of injustice with respect to pupils with common needs in this context. The concept of socially excluded locality is perceived inconsistently too. Although some participants to the qualitative interviews stated that it was not essential to their teaching practice, others mentioned it as an important clue to understand the specific educational needs of their pupils.

While in Krnov, a circumspect consensus accepting the status quo and the transformation steps can be felt, the educators and other education actors in Sokolov show quite different perspectives. The attitude indicators of the empiric study show better success of transformation from the perspective of social inclusion in Krnov, as compared to Sokolov, which can be expressed for example by lower declared tension in inter-ethnic relationships (the education of the Roma who constitute a substantial part of socially disadvantaged pupils is less loaded by emotions) or by the fact that, as compared to 
Sokolov, the status quo is accepted more positively and that there is more confidence in some inclusive steps (remedial class programs, work with the children's parents, work of the teacher's assistant) and in positive results of the transformation with respect to education of socially disadvantaged pupils.

While Sokolov was typical by different perspectives and emotional tone with respect to education of socially disadvantaged (mainly Roma) pupils, the actors of Krnov succeeded in creating an innovative inclusive model that tries to act upon the social and cultural influences included in education. It was based rather on practical needs and on personal familiarization with the conditions of life in the socially excluded locality than on theory. Nevertheless, this text is not aimed at evaluating the educational systems and transformation steps of both towns but at contributing to the discussion of the problem of education of socially disadvantaged pupils. The above stated findings indicate primarily a disunited understanding of the given concept and the differences of the practical solution of education of socially disadvantaged pupils. On the basis of the given findings and of theoretical research, we will try to elaborate further the concept of social disadvantage and to submit recommendations aimed at practice.

\section{Conclusions, discussion}

The parents from the socially excluded environment include many parents who accept the value of education, wishing that their children have higher education than they have and that they are more successful on the labour market. But they do not dispose of the necessary cultural capital that they could invest in their children (for example they are not able to correct a Czech homework without self-learning). The notion of (subjective) lack of interest in school is only partially true and it must be indispensably completed with the notion of (objective) barriers preventing the creation of the team background needed for individual school success of pupils, and the issue of overcoming the objective barriers should be dealt with. Our study identified that different types of respondents refuse or do not reflect the issue of objective barriers (contrary to the subjective ones), and that is why it cannot be dealt with. The annex to the study includes photographic documentation from a socially excluded locality, underlining the existence of the objective education barriers.

The study was focused, with respect to the transformation steps, primarily on the education of socially disadvantaged pupils from among the Roma. But we consider significant the finding from Krnov, stating that socially disadvantaged pupils can be commonly found also among the majority population. The study also identified a great inhomogeneity (and also vagueness, for many respondents) of the concept of social disadvantage. Based on the study and on theoretical research, we suggest distinguishing the following three dimensions of the concept of social disadvantage:

1. Social disadvantage as a manifestation of alienation from the values of the majority society, combined with social marginalization. In this respect, social disadvantage 
is often linked to unemployment, dependence on social benefits, higher tolerance to pathological behaviour. It is characterized by orientation on the present and by renunciation of the value of work or education. This dimension of social disadvantage is based on the concept of the poverty culture (Toušek, 2006; Lewis, 2006) as a specific subculture of poor people, leading to generational reproduction of poverty. At present, the concept of poverty culture is mingled with the concept of social exclusion in relation to socially excluded localities. But the study shows that even families from socially excluded localities do not completely pass over the value of education and that there may be families that view the education as a hope to break out from the marginal social position (compare Němec et al., 2010a).

2. Social disadvantage as a consequence of material poverty: low income, overindebtedness, frequent in present households of single parents (compare Horáková et al., 2013). But poverty is not linked to separation from the values of the majority society connected with work or education. However, poverty may be linked to some stigmatization or exclusion from some school activities.

3. Social disadvantage as manifestation of cultural difference: linked with national and ethnic minorities, families of asylum seekers or refugees. Cultural difference may be also linked with lack of knowledge of the Czech language and with problems to adapt to the school culture. But cultural difference need not be linked to social marginalization; the family of a national minority member may even have a high socioeconomic status ${ }^{5}$.

In our opinion, the above stated three dimensions of social disadvantage in education establish a situation requiring support or specific approach. But each of the dimensions requires a different approach. Passing over the social dimensions of education and stressing the allegedly equal conditions of the pupils may contribute to easier reproduction of social disadvantage ${ }^{6}$.

In our opinion, broader social and cultural context of education, exceeding the level of pedagogical-psychological diagnostics or didactics, should be considered at the faculties of education when preparing the educators already. In our opinion, the present reflection of education often overlooks the social dimension of education in its nontrivial form. Social disadvantage is another "handicap" than the handicaps caused by the individual's health or mental condition. Nevertheless, sociological thinking rather points out the range of overlooked aspects and unintentional consequences instead of offering unambiguous methodical and diagnostic tools.

\footnotetext{
$\mathbf{5}$ For example, when interviewing the educators in Sokolov, the opinion of trouble-free character of the Vietnamese minority in education could be heard. As an example of a high socio-economic status, we can present the picture of an asylum seeker from the Arabic world who has medical education.

${ }^{6}$ The reproduction of social status through the educational system does not necessarily concern only socially disadvanted people but also families of manual workers (compare Katrňák, 2004).
} 
We see a potential enrichment in the development of social educational science (for definition of social educational science see Kraus, 2008; Němec et al., 2010b) and its more intensive application at schools and in preparation of future teachers. Not only because of greater analytical closeness to the sociological way of thinking, as against special educational science, but also because of greater closeness to social work and helping professions that are able to identify more sensitively the social disadvantage and work better with it. In this respect, a social educator or social-educational knowledge can facilitate not only the communication with the families of socially disadvantaged pupils but also with the non-profit sector, which is an important partner of the school when overcoming social barriers in approach to education. A contribution of social educational science can consist also in more accurate and more detailed elaboration of the concept of social disadvantage for the needs of educational sciences and of educational practice. While the classifications of health handicap or health disadvantage rely on relatively reliable medical or pedagogical-psychological diagnostics, we feel that it is much more difficult to create a reliable objective diagnostic tool for social disadvantage. Additionally, the issue of social disadvantage exceeds by far the educational process that takes place in a specific class or school. Another problem consists in the obvious stigmatization linked with such diagnose. It will not be perceived as a conclusion of the pupil's drawback but as a conclusion of the situation of the whole family.

From the perspective of social pathology, we can observe that the presence / absence of social pathology is what sets apart the individual dimensions of the concept of social disadvantage. It is present only in its first dimension. But without an adequate intervention, it may concern the other two above stated dimensions after some time.

Nevertheless, we should be aware that although social marginalization is related in this conceptualization with alienation from the values of the majority society and also with social pathology, we must not link it only with the problem of "asociality" of some citizens. On the contrary, the authors perceive it as a consequence of structural inequality, and in this sense, the use of the concept of social pathology should not tempt us to assume the view contributing to the marginalization.

\section{References:}

Act No. 561/2004 Coll. on Pre-school, Basic, Secondary, Tertiary Professional and Other Education, as ammended. [online]. https://www.zakonyprolidi.cz/cs/2004-561.

SÚ. (2015). Rozvodovost. [Divorce Rate]. [online]. Accessed 30 December 2015. https:// www.czso.cz/csu/czso/rozvodovost.

Decree No. 72/2005 Coll. on Providing Advisory Services in Schools and School Advisory Centres, as amended. [online]. https://www.zakonyprolidi.cz/cs/2005-72. 
Decree No. 73/2005 Coll. on Education of Children, Pupils and Students with Special Educational Needs and the Exceptionally Gifted, as amended. [online]. http://www. msmt.cz/dokumenty/vyhlaska-c-73-2005-sb-1.

GAC. (2015). Analýza sociálně vyloučených lokalit v ČR. [Analysis of Socially Excluded Localities in the Czech Republic]. Prague: GAC.

Horáková M. et al (2013). Př́jmová chudoba a materiální deprivace v České republice podle indikátorů EU - vývoj v důsledku krize, fiskální konsolidace a sociální reformy. [Income poverty and material deprivation in the Czech Republic, as measured by the development of the EU as a result of the crisis, fiscal consolidation and social reform]. Prague: VÚPSV.

Hůle D. et al. (2011). Situační analýza Sokolov. [Situational Analysis Sokolov]. Prague: Demografické informační centrum. [Demographic Information Centre].

Janák, D., \& Stanoev M. a kol. (2015). Rozšírit řečiště hlavního vzdělávacího proudu; Sociální inkluze žáků a transformace vzdělávacího systému v Krnově a v Sokolově. [Extend bed mainstream education; Social inclusion of pupils and the transformation of the educational system in Krnov and Sokolov]. Opava: Silesian University in Opava.

Kaleja M. et al. (2011). Žák se speciálními vzdělávacími potrebami v pedagogické komunikaci. [Pupil with Special Educational Needs in Teaching Communication]. Ostrava: Faculty of Education, University of Ostrava.

Kaleja, M. (2015). (Ne)pripravený pedagog a žák z prostředí sociální exkluze. [(Un) prepared Teacher and Pupil in an Environment of Social Exclusion]. Opava: Silesian University in Opava.

Kaleja, M. et al. (2015). Etnografie školy jako edukační realita současnosti. [Ethnography School as an Educational Reality Now]. Opava: Centre of Empirical Research FPP SU.

Katrňák, T. (2004). Odsouzeni k manuální práci: vzdělanostní reprodukce $v$ dělnické rodině. [Condemmed to Manual Labor: Educational Reproduction in a Working-Class Family]. Prague: Sociologické nakladatelství [Sociological Publishing House].

Keller, J. (2011). Nová sociální rizika. [New Social Risks]. Prague: Slon.

Kolaříková, M. (2015). Dítě předškolního věku v prostředí sociální exkluze. [Preschool Child in Socially Excluded Environment]. Opava: Silesian University in Opava.

Kraus, L. (2008). Základy sociální pedagogiky. [Basics of Social Pedagogy]. Prague: Portál.

Lewis, O. (2006). Kultura chudoby. [Culture of Poverty]. In T. Hirt \& M. Jakoubek (Eds.), Romové v osidlech sociálního vyloučení [Roma in the Clutches of Social Exclusion] (pp. 401-412). Plzeň: Vydavatelství a nakladatelství Aleš Čeněk. [Aleš Čeněk Publishing]. 
MPSV. (2013). Koncepce prevence a řešení problematiky bezdomovectví v ČR do roku 2020. [Concept of Prevention and Tackling Homelessness in the Czech Republic until 2020]. Prague: MPSV.

MPSV. (2015). Statistická ročenka z oblasti práce a sociálních věcí. [Statistical Yearbook of Labor and Social Affairs]. Prague: MPSV.

MŠMT. (2015). Nejčastější dotazy k novele vyhlášky č. 73/2005 Sb., ve znění vyhlášky č. 147/2011 Sb. [FAQ on the Amendment of Decree no. 73/2005 Coll., As amended by Decree no. 147/2011 Coll.]. [online]. Accessed 30 December 2015. http://www.msmt.cz/ vzdelavani/socialni-programy/nejcastejsi-dotazy-k-novele-vyhlasky-c-73-2005-sb-ve-zneni

Němec, J. et al. (2010a). Edukace romských žáků v zrcadle výzkumných šetření. [Education of Roma Pupils in the Mirror of Researches]. Brno: Masaryk University.

Němec, J. et al. (2010b). Výzkum zaměřený na... Základní směry výzkumu katedry sociálni pedagogiky PdF MU. [Research Focused on ... Basic Research Directions of the Department of Social Education FE MU]. Brno: Masaryk University.

Szczepaniková, A. et al. (2013). Situační analýza Krnov. [Situation Analysis Krnov]. Prague: Spot.

Švejdová, Z. (2015). V česku přibývá dlužníků, kteří mají více exekucí najednou. [In the Czech Republic there are more and more borrowers who have multiple executions at a time]. Český rozhlas. [Czech Radio]. [online]. Accessed 30 December 2015. http://www. rozhlas.cz/zpravy/domaciekonomika/_zprava/v-cesku-pribyva-dluzniku-kteri-maji-viceexekuci-najednou--1541121.

Toušek, L. (2006). Kultura chudoby, underclass a sociální vyloučení. [Culture of Poverty, Underclass and Social Exclusion]. In T. Hirt \& M. Jakoubek (Eds.), Romové v osidlech sociálního vyloučení [Roma in the Clutches of Social Exclusion (pp. 288-321). Plzeň, Vydavatelství a nakladatelství Aleš Čeněk. [Aleš Čeněk Publishing].

Vítková, M. et al. (2007). Vzdělávání žáků se speciálními vzdělávacími potřebami I. [Education of Pupils with Special Educational Needs I.]. Brno: Paido.

Zezulková, E. (2015). Vybrané faktory komunikační kompetence žáků v primárním vzdělávání. [Selected Factors of Communicative Competence of Pupils in Primary Education]. Opava: Silesian University in Opava.

Zezulková, E., \& M. Kaleja. (2016). Heterogenita žáků základních škol ve speciálněpedagogické diagnostice. [Heterogeneity of Primary School Pupils in Special Education Diagnostics]. In P. Franiok (ed.), Pedagogická diagnostika a evaluace. Speciálněpedagogická diagnostika v inkluzivním vzdělávání. [Pedagogical Diagnostics and Evaluation. Special Education Diagnostics in Inclusive Education] (pp. 15-24). Ostrava: Faculty of Education. 
Annex: Photographic documentation from the socially excluded locality of Krnov (autor: Jindřich Štreit)
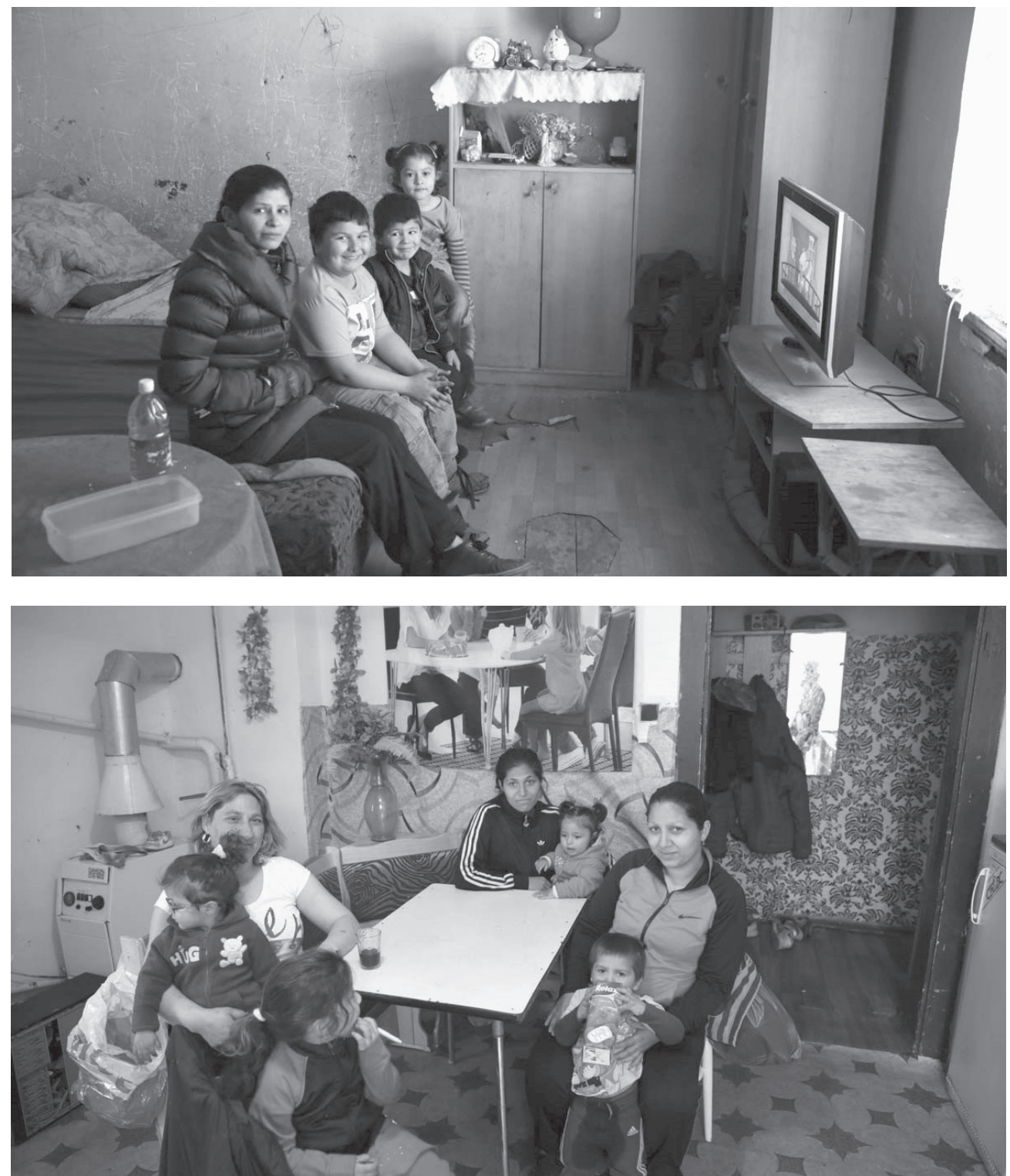

Comments to the photographs: The acquisition of own housing and the operational costs of housing probably constitute the greatest part of standard costs of living in most European societies, regardless of the fact that there are great differences in housing 
conditions. The photographs in this chapter show two Roma families. The pictures show us that in a family in a socially excluded environment, it is not commonplace for each child to have their own desk to do their homework; in this environment, it would definitely be a luxury that can hardly rank among the priorities of housing space planning and of household expenses. The children must do with the common table or the coffee table in the living room that obviously was not brought to the household from the lkea department store. Our pictures show Roma families, because the field work and the photographer's interest was focused on making pictures of the Roma, but the same applies also to non-Roma families.

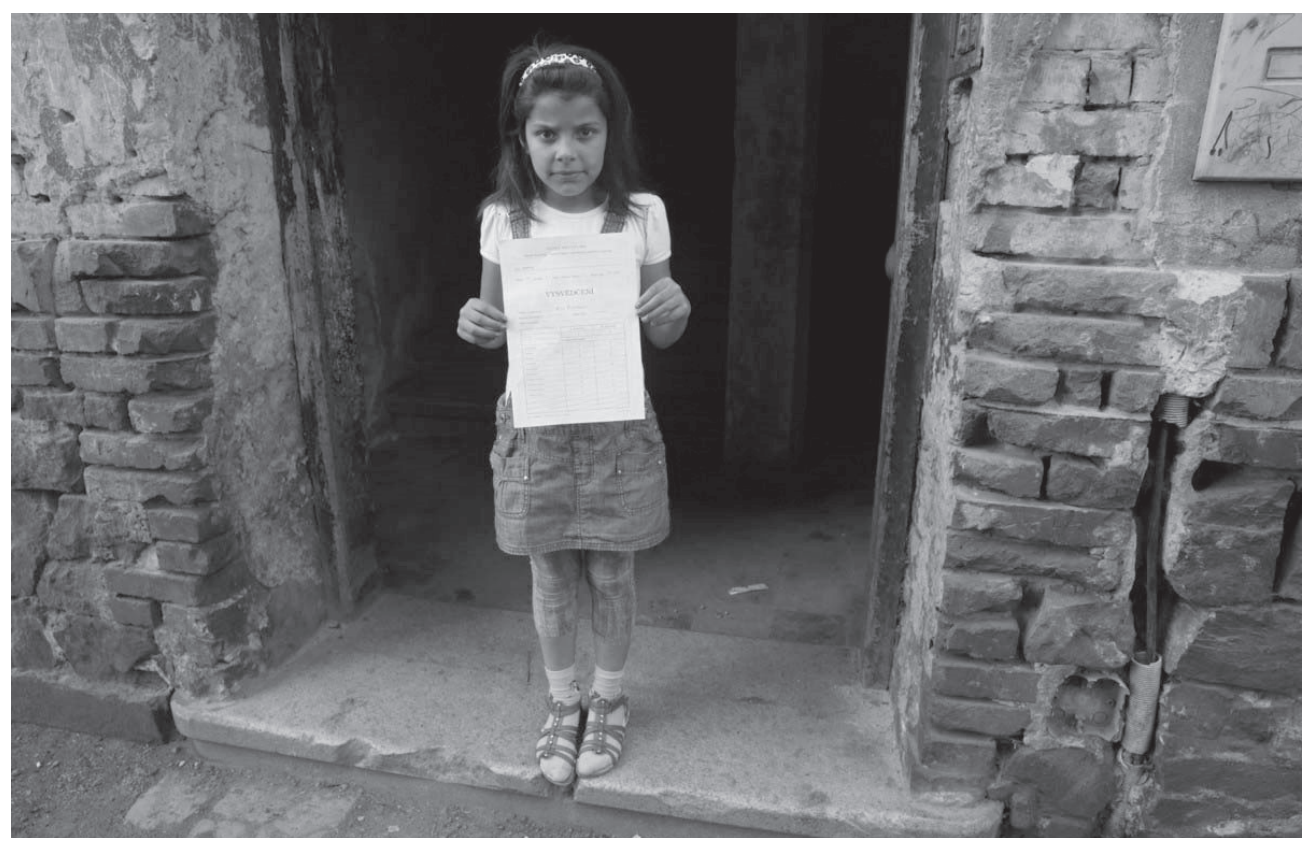

Comments to the photograph: With respect to social exclusion and integration, it is not so important whether we live in a battered block of flats at the beginning of our life cycle, but how we succeed in passing the school education system. Education keeps being the most important variable for the success in the labour market. Children who attended the kindergarten or another type of preschool preparation are statistically more successful at the elementary school. Children who succeed at the elementary school are more successful at the secondary school. Successful secondary school graduates have a good position in the labour market. However, children from battered blocks of flats attend statistically less often the kindergarten, which places them in an unfavourable position from the perspective of progress in other degrees of the educational system and finally of the labour market. Social disadvantage can smoothly pass into social exclusion. 


\section{Authors}

Mgr. Martin Stanoev, Ph.D.

Faculty of Public Policies, Silesian University in Opava

Centre of Empirical Research

Bezručovo nám. 885/14, 74601 Opava, The Czech Republic martin.stanoev@fvp.slu.cz

PhDr. Dušan Janák, Ph.D.

Faculty of Public Policies, Silesian University in Opava

Centre of Empirical Research

Bezručovo nám. 885/14, 74601 Opava, The Czech Republic janak@fvp.slu.cz

Mgr. et Mgr. Kateřina Tvrdá, Ph.D.

Faculty of Public Policies, Silesian University in Opava

Institute of Central European Studies

Bezručovo nám. 885/14, 74601 Opava, The Czech Republic

katerina.tvrda@fvp.slu.cz 